\title{
AN EXPLORATION OF THE RELATIONSHIP BETWEEN LEADERSHIP STYLES AND THE IMPLEMENTATION OF TRANSFORMATION INTERVENTIONS
}

\author{
J NAIDU \\ M S VAN DER WALT \\ Department of Human Resource Management \\ University of Johannesburg
}

\begin{abstract}
The objective of this research was to determine whether a relationship exists between the way in which subordinates experience their managers' leadership styles and the influence of such leadership styles on the implementation of transformation interventions. A two-phase triangulated research design was employed where the qualitative phase preceded the quantitative phase. Ninety six $(\mathrm{N}=96)$ respondents from a mining company participated in the survey. Results indicate a statistical and meaningful correlation between Integrated Leadership styles and transformation interventions but no correlation between Directive Leadership and implementation of transformation interventions.
\end{abstract}

\section{OPSOMMING}

Die doel van hierdie studie was om te bepaal of daar ' $n$ verband bestaan tussen ondergeskiktes se ervaring van hulle bestuurder se leierskapstyl en die invloed daarvan op die implementering van transformasie-intervensies. ' $n$ Tweefasige intermetodiese kruisvalidasie-ontwerp is gebruik waar die kwalitatiewe fase die kwantitatiewe fase voorafgegaan het. Ses-en-negentig $(\mathrm{N}=96)$ respondente van ' $\mathrm{n}$ mynmaatskappy het aan die opname deelgeneem. Resultate dui daarop dat daar 'n statistiese en ook praktiese betekenisvolle korrelasie bestaan tussen die Geintegreerde Leierskapstyle en die transformasie-intervensies. Daar is egter geen korrelasie tussen Directive Leierskap en die implementering van transformasie-intervensies nie.

Leadership is one of the main drivers of organisational success for the twenty first century and beyond. The external environment in which organisations operate is changing unpredictably, so much so, that transformation or change management has become a necessity and has moved from being mere buzzwords to becoming the accepted norm. (Kouzes \& Posner, 2002 and Macnamara, 2004). Rampant change has become the benchmark for most organisations and as it is the leadership of most organisations who drive the change, it is they who are constantly challenged.

The business world is becoming much more competitive and volatile. Businesses are being faced with technological change, markets that have been de-regulated, intensive competition from local and international companies and more demanding customers. In addition to these factors South African organisations have been faced with identifying coping strategies for a culturally diverse workforce and an increase in demand for skilled personnel. The net result is that doing what was done yesterday, or doing it a little better, is no longer a guarantee of success. Instead major changes in business practices, methodologies and leadership competence are necessary to survive and compete effectively in this new environment. Kotter (1998) advises that more change always demands more leadership. Hence, the importance of leadership in implementing change or transformation interventions. Most organisations, however, do not pay enough attention to leadership and leadership styles when they implement transformation interventions.

It has been predicted widely in the business community that the only organisations that will thrive in the contemporary competitive environment will be the ones that can focus the synergy of their workforce. Put differently, successful organisations need to have leaders implementing the right leadership approach with the right people at the right times (Beck \& Yeager, 2001; Berr, Church \& Waclawski, 2000).

But what exactly is the 'right' leadership style and when are the right times to use it? Is there any relationship between particular

Requests for copies should be addressed to: J. Naidu,

pamnaidu@absamail.co.za leadership styles and influencing a workforce to accept and implement transformation? Can a leader motivate or influence employees who are resistant to change to accept and become part of a shared vision merely by using a particular leadership style? These are some of the questions this research article seeks to provide answers for.

The Problem identification and statement: There is an urgent need for transformation in our country, which in turn requires strong leadership to make this transformation happen. Leaders are the initiators, implementers and evaluators of organisational change and therefore leadership roles take on a central position amidst organisational change. Leaders set the pace and subordinates should follow.

It is essential for organisations to transform in order to survive and progress in the modern world. Therefore they need leaders who can initiate and implement the necessary transformation interventions. But leaders do not operate in a vacuum. They have followers whom they have to take with them in moving towards the required goal. Yet it is fact that leaders have different leadership styles and that some leadership styles may be more effective than others in specific circumstances. If this is true, it may pose a problem to organisations, for ineffective leaders may not bring about the desired organisational transformation. This in turn, could lead to huge monetary losses or even the demise of the organisation over time.

This research will answer the question "Does the way in which subordinates perceive their management's leadership style influence the successful implementation of transformation interventions?" The research therefore aimed to test the null hypothesis that there is no relationship between leadership style and the implementation of transformation interventions.

The organisation in which this research was based, is classified as a mining company according to the mining sector. This organisation, like all other mining organisations, is governed by the Mining Charter. This charter is a proactive strategy of change to foster and encourage Black Economic Empowerment and the advancement of historically disadvantaged South Africans in the form of both, skills development and specific employment 
equity targets. In addition to this, the charter also prescribes transformation at the tiers of ownership, procurement and rural development. Some of the penalties for non-compliance include loss of mining licences and huge fines. Thus, transformation must be seen as a priority and leaders in the mining industry must exhibit leadership styles that will effectively drive transformation interventions. However, the need for transformation is not only a priority in the mining industry. It is indeed a priority for any South African organisation that wants to compete globally.

The impact of the Mining Charter is that organisations need to implement specific transformation interventions, which need to be driven by leaders. Leaders have different leadership styles. Their different leadership styles may cause them to influence transformation differently. Some leaders can therefore be seen as more effective, some as less effective. Less effective leadership styles can be costly to the organisation in terms of money and time. The aim was therefore to assess the link, if any, between a manager's style of leadership and the implementation of transformation interventions in the mining industry.

\section{Leadership and leadership styles}

The terms "management" and "leadership" have many definitions but for the purposes of this research the term "leadership" will encompass and refer to management, for managers lead change and drive transformation in organisations. Research supports this view. Kotter (1998) states that leadership and management are "complementary systems of action" and that while management is about coping with complexity, leadership is about coping with change. According to Williams, Woodward and Dobson (2002) all managers are leaders for they help others to identify and achieve goals. This, to them, is a critical leadership function.

A literature review reveals that there is no single and clearly agreed upon definition of leadership. Kanji and Moura (2001, p. 709) stated there are "almost as many different definitions of leadership as there are researchers who have attempted to define the concept."

Other views on leadership include the following:

- Kouzes and Posner (2002) see leadership as a process ordinary people use when they are bringing forth the best from themselves and others. Leaders, they feel, are credible, inspire a shared vision, enable others to act, model the way and recognise their employees' contributions.

- Paul Taffinder, (cited in Burton, 2002, p. 22) regards leadership as "getting people to do more than they think is possible or than they want to do."

- "Leaders empower others to make decisions" (Havenga, 2002, p. 5 quoting Tom Peters, world-renowned management guru).

This study does not intend to resolve the definitional controversy of leadership by providing a single best definition. Instead it approaches leadership as the ability to influence people to participate in transformation interventions and align their individual goals with those of the organisation.

Literature on leadership identifies transactional and transformational leadership as the two most dominant styles of leadership. This study focused on a broader view of leadership styles and incorporated the four-factor leadership model of Manz and Sims which included the "Directive" or "Strong Man", "Transactional", "Visionary Hero" or "Transformational" and "SuperLeader" or "Empowering" leadership styles (Bass \& Avolio, 1997; Manz \& Sims, 1991).

"Directive" or "Strong Man" type of leadership style represents a highly directive, occasionally punitive and dictatorial individual. He relies on his formal position to exert power and makes unilateral key decisions in his organisation. His subordinates have to comply (Manz \& Sims, 1991).
It is this type of leader who sizes up the situation and delivers commands to his workers based on what he regards as his superior strength and skill. If his commands are not followed he will deliver some significant form of punishment to the guilty party. The "Strong man" or "Directive" leadership style is based on intimidation, contingent reprimand, assigned goals and fear-based compliance (Manz and Sims, 1991, p. 19; Pearce \& Sims, 2002).

"Transactional" leaders are often seen as traditional leaders who reward their followers for task completion and compliance. Followers are made aware of what their leader regards as acceptable standards of performance and the rewards they will receive should they achieve these acceptable standards of performance (Hartog \& Van Muijen, 1997). This type of leadership is based on a rational exchange approach (exchange of rewards for work performed). The focus is on goals and rewards. In this type of leadership style the leader's power stems from his ability to provide rewards. Typical leader behaviours include interactive goal setting, contingent material reward, contingent personal reward and personal recognition (Manz \& Sims, 1991).

Bass and Avolio (1997) conclude that the following focus areas are key to transactional leaders: rewards and incentives to motivate followers, close monitoring of followers to identify mistakes made by followers and taking corrective action where necessary.

"Transformational" leaders, unlike transactional leaders, are said to inspire their followers to such an extent that they work towards the good of the company (Bass \& Avolio, 1997; Godardt \& Lenhardt, 2000; Thorn, 2003). The following dimensions are common to transformational leaders: charismatic leadership (or idealised influence), inspirational motivation, intellectual stimulation, idealised behaviours and idealised attributes (Pearce \& Sims, 2002, p. 175). The leader articulates a compelling optimistic vision of the future. He takes a stand on controversial issues and is confident that goals will be achieved. In this way he inspires his followers.

The leader provides intellectual stimulation for his followers by encouraging them to see solutions to problems from different perspectives and to be creative when completing tasks. The leader places emphasis on values, beliefs, morals and trust in working towards a common mission (Bass \& Avolio, 1997). Idealised attributes refer to leaders who are emulated by their followers for they display power, confidence and make sacrifices for the benefit of others (Bass \& Avolio, 1997; Godard \& Lenhardt, 2000).

Typical leader behaviours include communication of the leader's vision, emphasis on leader's values, stimulation, challenge to the status quo and inspirational persuasion (Manz \& Sims, 1991).

Manz and Sims (2001) referred to the "Empowering Leader" or "SuperLeadership" as representing a paradigm shift. This is the kind of leader who leads others to lead themselves. The empowering leader creates followers who are effective selfleaders. Their followers are empowered to such an extent that they eventually are capable of leading themselves and do not need the leader any longer. Typical leader behaviours include becoming and modelling self-leadership, creating positive thought patterns and developing self-leadership through reward and constructive reprimand (Salam, Cox \& Sims, 1997). The "SuperLeader's" strength is said to be measured by his ability "to maximise the contributions of others through recognition of their right to guide their own destiny," rather than his ability "to bend the will of others to his or her own" (Manz \& Sims, 1991, p.18). Typical leader behaviours include independent action, self-reward, self-leadership, participative goal-setting and encouraging teamwork (Pearce \& Sims, 2002). 
In assessing the relationship between leadership styles and transformation interventions it is important to understand what exactly is meant by transformation interventions.

\section{Transformation Interventions}

We now take a look at scholars' views on transformation interventions and how they need to be recognized.

Heifetz and Laurie (2002) see transformation as "adaptive challenges" that force leadership to clarify their values, develop new strategies and mobilize their workforce to do work that is different to what they were used to. Transformation is seen by Applebaum and Wohl (2000) as a total metamorphosis, as something totally different from change. Transformation is creating something new, not improving on something that already exists, they say. Transformation interventions for purposes of this research study would, however be seen as interventions used to bring about change and mobilize the workforce to do things differently. Transformation will not be seen as a total metamorphosis.

Linkage Inc. researched eight major manufacturing and pharmaceutical firms and found that the top five transformation interventions with a link to leadership are: action learning, 360 degree feedback, exposure to senior executives, exposure to strategic agenda and external coaching (Giber, Carter \& Goldsmith, 2000).

For the purposes of this proposed study six transformation interventions were selected. They are the strategies presently being utilised in the organisation under study, and include: communication, empowerment, diversity management, training and development, performance management and change management. Why the selection of these strategies and not any others?

Communication is vital for an individual to do his job properly. Individuals who understand the why, what, when and how of changes to be made will feel more confident in predicting the consequences of change according to Williams et al. (2002). Empowering individuals to make decisions is an important aspect of including individuals in the change process. Mosia (2003, p.39) defines empowerment as the process of passing authority and responsibility to individuals at lower levels of the organisation. He adds further that leaders must empower their subordinates so as to create an environment of trust and motivation. Performance management, a developmental tool, is helpful in setting achievable targets and measuring whether targets have been met or not. Similarly if change management is a planned process it can be an effective transformation strategy.

A job for life is no longer a realistic expectation. What was a job for life is now a life full of jobs (Peters, 2004, p.7). Individuals now have to think in terms of continuing education and this is where Training and Development becomes an important transformation strategy for organisations. Diversity management is another important transformation strategy as the South African workforce is made up of a culturally diverse workforce. Items measuring these strategies were developed in conjunction with the responses received from the management team when interviewed. These were then incorporated into a structured questionnaire.

An extensive pool of knowledge exists on leadership styles and transformation interventions as separate phenomena. However knowledge on how different leadership styles impact on the implementation of transformation interventions is limited. Although both the variables have been researched in separate studies, a mixed methodological approach incorporating both variables has not been undertaken. Here follows a discussion of what is already known regarding the issues of leadership style and the implementation of transformation interventions:
Thorn (2003) undertook a qualitative study and identified emerging findings on the current and future qualities and attributes of leaders of international organisations. Thorn's findings supported the principles and characteristics associated with transformational leadership. Her research indicated that leaders of international organisations need to adopt a transformational leadership style to effectively implement change. This research, although relevant to the topic of this research was done by interviewing twelve leaders from four international financial and development institutions. It was not done in a South African setting or in an organisation that falls within the mining sector.

Quantitative research aimed at identifying effective leadership for teamwork cross-nationally was done by Leslie and Van Velsor in 1998. Their research indicate that work teams can be unified through friendliness and clear task orientation. This research explored Eastern European and US perceptions of effective leadership. The study results indicate that unique value patterns are perceived in effective leaders. Once again, although this study is relevant to the topic, it was not based in a South African context.

Research already done in a South African setting regarding leadership and transformation indicates a void in scientific knowledge on how leadership styles could facilitate the implementing of transformation interventions in South Africa and it is to this gap that this study wants to add new knowledge.

Smit and Carstens (2003) focused their research on the influence leadership role congruence has on organisational change within three South African organisations in the manufacturing industry. Four leadership change roles (initiator, shaper, monitor and assessor) were identified and a set of competencies was developed for each leadership role. The research findings included, amongst others, that there was role congruence for the Initiator and Assessor roles as they influenced change outcome positively and that there was a lack of congruence for the shaper and Monitor roles as they had a negative influence on change outcome. The study was done quantitatively and in a manufacturing industry, not a mining industry.

The importance of leadership roles in the strategic management process was researched by Mosia (2003). He identified leadership as being of the "utmost importance in facilitating the establishment and sustainability of key strategic management processes". However, the study did not focus on specific leadership styles. Transformation can be classified as a key strategic management process since it is not negotiable. It is this void in linking leadership styles to effective transformation, that this study wishes to address.

Mester, Visser, Roodt and Kellerman (2003) researched relationships between leadership style and organisational commitment, job satisfaction, job involvement and organisational citizenship behaviour. They tested whether these relationships were stronger for transformational than for transactional leaders in a world class Engineering company in South Africa. Their findings were that transformational and transactional leadership did not correlate significantly with the constructs of job involvement and job satisfaction. There was a significant correlation between transformational leadership and organisational citizenship behaviour. There was a positive correlation of both transformational and transactional leadership and affective commitment. The focus in this study falls on leadership styles and not on transformation interventions. This study also has a quantitative basis and the participants were executives and senior managers only.

Transformational leadership was researched in the study "Transformational Leadership in Business organisations ascending to world-class status: A Case study in the Petrochemical industry" by De Kock and Slabbert (2003). 
Their aim was to prove that in order to achieve economic competitiveness; transformational rather than transactional leadership should be a core element in an organisation's ascent to 'world-class' status. This study revealed that in the petrochemical industry, transformational leadership was not up to expectation but also acknowledged that the organisation under study was still in the initial phases of the transformation process.

Theoretically the study will contribute to the existing pool of knowledge on how different leadership styles contribute to the effective implementation of transformation interventions.

This study will test the null hypothesis that there is no relationship between leadership style and implementation of transformation interventions. On a practical level the leaders in the specific company under study may use this knowledge to change or modify their personal leadership styles to more effectively implement transformation interventions. In general all employees and managers in the organisation should benefit if the transformation process is implemented more smoothly and successfully.

\section{RESEARCH DESIGN}

Quantitative and Qualitative research is often seen as representing two different paradigms or basic set of beliefs that guide research, each assuming different ontologies and epistemologies (Hathaway, 1995). Quantitative research is associated with numerative induction in that it "relies upon measurement, utilises statistics and will mean the same thing in different social, cultural and linguistic settings" (Bless \& Higson-Smith, 2000, p. 38).

Qualitative research, on the other hand, is difficult to define as "it can mean different things to different people" (Strauss \& Corbin, 1990, p.17). Denzin and Lincoln (2000) and Bogdan and Biklen (1998) support this view. Despite the difficulty in pinning down a single best definition, one of the major distinguishing characteristics of qualitative research is that the researcher attempts to understand people in terms of their own definitions of their world.

Employing both quantitative and qualitative research methods in a particular study is supported by various prominent social science researchers, including: Bless and Higson-smith (2000); Denzin and Lincoln (2000); Flick, (1998) and Strauss and Corbin (1990). Denzin and Lincoln (2000) refer to this method as "methodological triangulation" and more specifically as a "between-methods" approach (the use of different methods in relation to the same object of study). Creswell, Trout and Barbuto (2003) support the method of triangulation. In short: multiple methods can be used to secure an in-depth understanding of the phenomenon in question.

\section{Research methodology}

For the purposes of this research a two-phased triangulated or blended research design was used to achieve the research objectives (Creswell, Trout \& Barbuto, 2003). Both qualitative (Phase 1) and quantitative data (Phase 2) were used in the study. The qualitative (less dominant phase) preceded the dominant quantitative phase. Tashakkori and Teddlie (2003) refer to this type of design as a 'nested' design, as one method is given less emphasis but is clearly nested within the other. A similar research approach of triangulation was employed by Bussin (2003).

\section{Participants/Respondents}

Phase 1 (Qualitative)

5 Heads of Department (randomly selected) from the management team of 19 managers were interviewed to describe the transformational interventions they had launched, initiatives used to achieve these interventions, identify and list the outcomes they hoped to achieve with each intervention and rate or assess their outcomes numerically on a semantic differential scale ranging from 1 (not at all successful) to 5 (very successful). Responses received in the interviews were used to draw up questions for Section B of the questionnaire and supplement the literature review to be used in Phase 2 .

Phase 2 (Main Study - Quantitative)

In order to ensure representativeness the different departments were used as strata and within each department a random sampling method was used to select respondents. An alphabetised departmental list was used to identify every third person that was handed a questionnaire. The respondents were subordinates reporting to the 5 Heads of Departments who were interviewed in Phase one of the research. The sample population consisted of 96 respondents whose average age was 35,05 and average number of years at the company was 7,79 years. The range was 21 to 57 with fewer older respondents and is positively skewed.

\section{Measuring instruments}

A questionnaire consisting of 3 sections was used. (The questionnaire is available on request).

- Section A : Biographical Information

- Section B : Transformational Intervention Questionnaire

- Section C: Leadership Strategy Questionnaire II by Manz and Sims.

Phase 1

For the first part of the study, the HOD's responses were recorded via a semi-structured interview to elicit information about the way in which they perceive their own leadership styles and supplement the literature review on transformation interventions. The HOD's were asked to describe, amongst other things, the transformation interventions they had launched, initiatives used to achieve these interventions, list the outcomes they hoped to achieve with each intervention and rate the success of its implementation. The data obtained from the interviews was content analysed and used to generate questions for Section B of the questionnaire that was used in Phase 2 of the study.

Phase 2

The Transformational Intervention Questionnaire consisted of 30 items based on transformational interventions the HOD's had indicated they had launched. Transformation interventions such as communication, empowerment, diversity management change management, training and development and performance management were dimensions addressed in the questionnaire.

The Leadership Strategy Questionnaire consisted of 96 items and focused on the dimensions of "Directive", "Transactional", "Transformational" and "SuperLeadership" or "Empowering leadership". Subordinates' perceptions of leader behaviours exhibited by their managers were elicited via this questionnaire. Each of these dimensions in the Leadership Strategy questionnaire were analysed in terms of their sub-dimensions, which will be discussed in the analysis that follows.

The Leadership Strategy Questionnaire II is a standardised questionnaire that was initially researched on 702 managers in the defence industry in America. Based on this research 15 leader behaviours were identified and grouped into a four-factor leadership model consisting of the following four leadership styles: Directive, Transactional, Transformational and Empowering leadership styles (Manz and Sims, 1991). The reliability coefficient for each of the 15 dimensions ranged from 0,62 to 0,9 (Van der Heyde and Roodt, 2003). 


\section{RESULTS}

Phase 1

The interview schedule covered the following dimensions of transformation interventions communication, empowerment, change management, diversity management, performance management and training and development. The data obtained from the interview revealed that the management team interviewed rated themselves very high (4 out of 5) in terms of their effectiveness on all of the above transformational interventions, except for performance management. They admitted that performance management, still in its developmental stage, needed attention. The responses obtained from the interviews were used, in conjunction with theory, to draw up questions for Section B of the questionnaire that was developed for Phase 2 of the research.

\section{Phase 2}

Transformational Intervention Questionnaire

The Kaiser-Meyer-Olkin measure of sampling adequacy (MSA) was equal to 0,9 and the Bartlett test for sphericity was 493,01 $(\mathrm{p}<0,000)$ indicating that there was sufficient correlation in the correlation matrix to justify factor analysis. Due to the small sample size, that is 96 respondents, a factor analysis was subsequently done on the variables in each of the theoretical dimensions of the Transformational Intervention Questionnaire. The Principal Axis Factoring (PAF) method using a Varimax rotation was used. In each case the items reduced to one factor per dimension. The internal reliability of the dimensions was assessed by calculating the Cronbach Alpha coefficient. The Cronbach Alpha scores are displayed in Table 1.

TABLE 1

RELIABILITY SCORES OF THE TRANSFORMATION INTERVENTION QUESTIONNAIRE DIMENSIONS

\begin{tabular}{|c|c|c|c|}
\hline Dimension & $\begin{array}{l}\text { Cronbach } \\
\text { Alpha } \\
\text { Scores } \\
\text { Obtained }\end{array}$ & $\begin{array}{l}\text { Number } \\
\text { of Items }\end{array}$ & Example in Questionnaire \\
\hline Communication & 0,69 & 5 & $\begin{array}{l}\text { My HOD/Superintendent } \\
\text { welcomes feedback on } \\
\text { his/her management style. }\end{array}$ \\
\hline Empowerment & 0,83 & 5 & $\begin{array}{l}\text { My HOD/Superintendent } \\
\text { allows me to take initiative } \\
\text { in my job. }\end{array}$ \\
\hline $\begin{array}{l}\text { Performance } \\
\text { Management }\end{array}$ & 0,74 & 5 & $\begin{array}{l}\text { My HOD and I agree on } \\
\text { key performance objectives } \\
\text { at the start of a new job } \\
\text { or project. }\end{array}$ \\
\hline $\begin{array}{l}\text { Training and } \\
\text { Development }\end{array}$ & 0,83 & 5 & $\begin{array}{l}\text { My HOD/Superintendent } \\
\text { encourages me to study } \\
\text { further and develop } \\
\text { myself. }\end{array}$ \\
\hline Change Management & 0,73 & 5 & $\begin{array}{l}\text { Change in my organisation } \\
\text { is a well-planned process. }\end{array}$ \\
\hline $\begin{array}{l}\text { Diversity } \\
\text { Management }\end{array}$ & 0,82 & 5 & $\begin{array}{l}\text { My HOD/Superintendent } \\
\text { respects and tolerates } \\
\text { individual differences } \\
\text { in people. }\end{array}$ \\
\hline
\end{tabular}

An analysis of Table 1 reveals Cronbach Alpha scores higher than 0,6 . This confirms that the instrument was reliable. The overall scores ranged from 0,83 (Empowerment and Training and Development) to 0,69 (Communication).

The first order dimensions were subsequently subjected to a second order factor analysis. Principal Axis Factoring was used. The six first order factors reduced to a single order factor with reliability of 0,95 .
TABLE 2

ROTATED FACTOR MATRIX OF SECOND ORDER FACTOR ANALYSIS

\begin{tabular}{lc}
\hline \multicolumn{2}{c}{ Factor Matrix } \\
\hline & Factor 1 \\
TIQ - Empowerment & 0,926 \\
TIQ - Performance management & 0,902 \\
TIQ - Diversity management & 0,893 \\
TIQ - Communication & 0,867 \\
TIQ - Training \& Development & 0,865 \\
TIQ - Change management & 0,762 \\
\hline
\end{tabular}

Leadership Strategy Questionnaire II

A factor analysis was done on the items in each dimension separately since the number of respondents was too few. The aim of the factor analysis was to test the factors against the dimensions as identified in previous empirical research done on the Leadership Strategy Questionnaire. The following subdimensions linked to leadership style, were factor analysed: "Aversive behaviour", "Encourages self-reward", "Challenge the status quo", "Encourage teamwork", "Contingent material reward", "Assigned goals", "Vision", "Instruction and command", "Encourages opportunity thought", "Participative goal setting", "Contingent personal reward", "Contingent reprimand", "Idealism" and "Independent action". A factor analysis was not done on the sub-dimension, "Stimulation and Inspiration" as there were only two items in this dimension. Table 3 indicates the item loadings obtained from the factor analysis.

The internal reliability was tested using the iterative item loadings technique and the Cronbach Alpha coefficient scores obtained are reflected in Table 4 . The Cronbach Alpha scores ranged from 0,6 ("Instruction and Command") to 0,9 ("Participative goal setting") indicating that the instrument was reliable. In the first order factor analysis all theoretical dimensions reduced to one reliable factor per dimension except "Aversive behaviour" which reduced to 2 factors. All items in "Aversive behaviour," however, do form a reliable scale.

Table 5 demonstrates that second factor analysis (using Principal Axis Factoring and Oblimin with Kaiser Normalization Rotation method) reduced the 15 dimensions to 3 second order dimensions.

The following dimensions had the highest loading on factor 1: "Encourages Self-Reward", "Encourages Opportunity Thought", "Contingent Personal Reward", "Participative Goal-Setting", "Contingent Material Reward", "Assigned Goals", "Vision", "Stimulation and Inspiration", "Independent Action" and "Encourage Teamwork". The dimensions "Idealism", "Challenge to the Status Quo" and "Contingent Reprimand" had the highest loading on Factor 2. "Aversive behaviour" and "Instruction and Command" had the highest loading on Factor 3.

A Cronbach Alpha reliability score was obtained for each of the factors. The reliability of Factor 1 was 0,98 . The reliability of factor 2 was 0,88 and the reliability of factor 3 was 0,73 . Factor 1 will be called "Integrated leadership style" for it is a combination of all four leadership styles. Research on leadership styles (as was discussed under Leadership and Leadership styles) indicates that the leader behaviours such as "Encourages self-reward", "Encourages opportunity thought", "Participative goal-setting", "Independent action" and "Encourages teamwork" are associated with an Empowering 
TABLE 3

ROTATED FACTOR MATRIX (PER DIMENSION) OF THE DIMENSIONS OF THE LEADERSHIP STRATEGY QUESTIONNAIRE

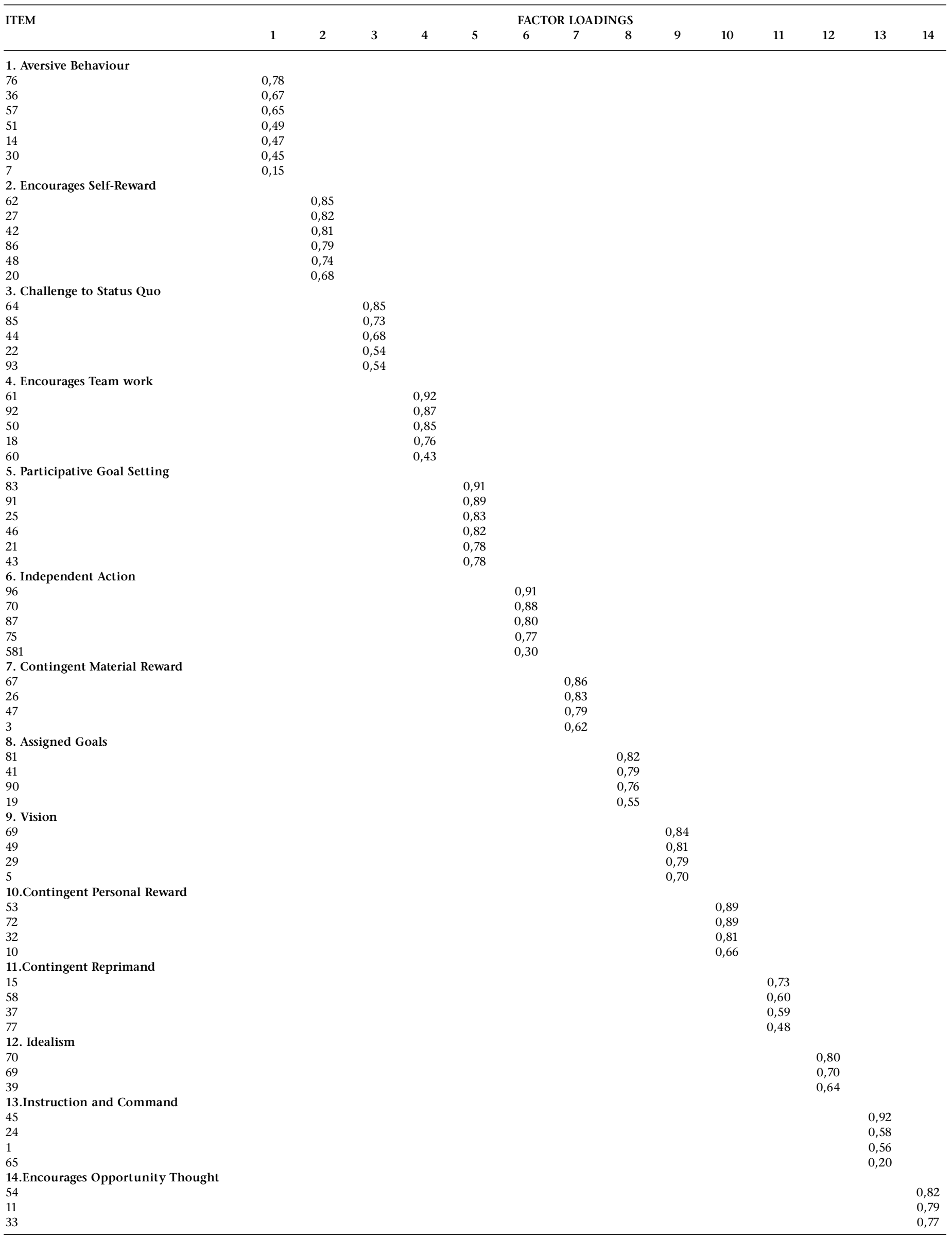


leadership style. "Contingent personal reward" and "Contingent material reward" are associated with Transactional leadership whilst leader behaviours such as "Vision" and "Stimulation and inspiration" are associated with a Transformational leadership style. "Assigned goals" is a leader behaviour associated with Directive leadership. Hence the term "Combined leadership style" for Factor 1 for it is a combination of Transactional, Transformational and Empowering leadership styles. Factor 2 will be referred to as "Transformational leadership style" as "Idealism" and "Challenging the status quo" are leader behaviours associated with a transformational leader. "Contingent reprimand", also a dimension in Factor 2, is associated with Directive leadership. However, since "Contingent reprimand" has a lower loading on Factor 2, Factor 2 will be referred to as "Transformational leadership". Factor 3 will be referred to as "Directive leadership" for instruction and command and aversive behaviour are dimensions of this type of leadership.

Table 4

RELIABILITY COEFFICIENTS OF THE DIMENSIONS OF THE LEADERSHIP STRATEGY QUESTIONNAIRE

\begin{tabular}{llc}
\hline Dimension & Cronbach Alpha Coefficients & $\begin{array}{c}\text { No. of } \\
\text { items }\end{array}$ \\
\hline Aversive Behaviour & 0,81 & 7 \\
Encourages Self-Reward & 0,90 & 6 \\
Challenge to Status Quo & 0,80 & 5 \\
Encourages Teamwork & 0,87 & 5 \\
Participative Goal Setting & 0,93 & 6 \\
Independent Action & 0,85 & 5 \\
Contingent Material Reward & 0,85 & 4 \\
Assigned Goals & 0,82 & 4 \\
Vision & 0,86 & 4 \\
Contingent Personal Reward & 0,88 & 4 \\
Contingent Reprimand & 0,69 & 4 \\
Idealism & 0,75 & 3 \\
Instruction and Command & 0,64 & 4 \\
Encourages Opportunity Thought & 0,84 & 3 \\
\hline
\end{tabular}

TABLE 5

ROTATED PATTERN MATRIX OF THE DIMENSIONS OF THE LEADERSHIP STRATEGY QUESTIONNAIRE

\begin{tabular}{|c|c|c|c|c|}
\hline \multicolumn{5}{|c|}{ Pattern Matrix } \\
\hline & \multicolumn{2}{|c|}{ Factor Loadings } & & \multirow{2}{*}{$\begin{array}{l}\text { Integrtaed } \\
\text { leadership } \\
\text { style }\end{array}$} \\
\hline & 1 & 2 & 3 & \\
\hline LSOII - Encourages Self-Reward & 0,90 & & & \\
\hline LSOII - Encourages Opportunity Thought & 0,83 & & & \\
\hline LSOII - Contingent Personal Reward & 0,82 & & & \\
\hline LSOII - Participative Goal-Setting & 0,81 & & & \\
\hline LSOII - Contingent Material Reward & 0,74 & & & \\
\hline LSOII - Assigned Goals & 0,73 & & & \\
\hline LSOII - Vision & 0,65 & & & \\
\hline LSOII - Stimulation and Inspiration & 0,58 & & & \\
\hline LSOII - Independent Action & 0,55 & & & \\
\hline LSOII - Encourage Teamwork & 0,55 & & & \\
\hline LSOII - Idealism & & 0,81 & & $\begin{array}{l}\text { Transforma- } \\
\text { tional } \\
\text { leadership } \\
\text { style }\end{array}$ \\
\hline LSOII - Challenge to the Status Quo & & 0,78 & & \\
\hline LSOII - Contingent Reprimand & & 0,72 & & \\
\hline LSOII - Aversive Behaviour & & 0,47 & & $\begin{array}{l}\text { Directive } \\
\text { leadership } \\
\text { style }\end{array}$ \\
\hline LSOII - Instruction and Command & & & 0,42 & \\
\hline
\end{tabular}

Since an oblique rotation was used in the second order factor analysis, Factor 1, Factor 2 and Factor 3 can be correlated. The correlations between the Factors are indicated in Table 6 .

ANOVAs (one way analysis of variance) and T-tests were used to establish whether there were any significant differences between respondents and their age, educational qualifications and number of years in the company. The tests revealed no significant difference $(\mathrm{p}<0,05)$. This implies that subordinates' perceptions of their manager's leadership style are not determined by their age, number of complete years in the company or their educational qualifications.

TABLE 6

CORRELATIONS BETWEEN SECOND ORDER FACTORS

\begin{tabular}{|c|c|c|c|c|}
\hline & & LSOII - Second order factor 1 & LSOII - Second order factor 2 & LSOII - Second order factor 3 \\
\hline \multirow[t]{3}{*}{ LSOII - Second order factor 1} & Pearson Correlation & 1 & $0,645(* *)$ & $-0,090$ \\
\hline & Sig. (2-tailed) & & 0,000 & 0,420 \\
\hline & $\mathrm{N}$ & 86 & 81 & 83 \\
\hline \multirow[t]{3}{*}{ LSOII - Second order factor 2} & Pearson Correlation & $0,645(* *)$ & 1 & 0,091 \\
\hline & Sig. (2-tailed) & 0,000 & & 0,399 \\
\hline & $\mathrm{N}$ & 81 & 90 & 88 \\
\hline \multirow[t]{3}{*}{ LSOII - Second order factor 3} & Pearson Correlation & $-0,090$ & 0,091 & 1 \\
\hline & Sig. (2-tailed) & 0,420 & 0,399 & \\
\hline & $\mathrm{N}$ & 83 & 88 & 93 \\
\hline
\end{tabular}

TABle 7

CORRELATIONS OF THE SECOND ORDER FACTORS

\begin{tabular}{|c|c|c|c|c|c|}
\hline \multicolumn{6}{|c|}{ Correlations } \\
\hline & & $\begin{array}{l}\text { TIQ - Second } \\
\text { order factor }\end{array}$ & $\begin{array}{l}\text { LSOII - Second } \\
\text { order factor } 1\end{array}$ & $\begin{array}{l}\text { LSOII - Second } \\
\text { order factor } 2\end{array}$ & $\begin{array}{l}\text { LSOII - Second } \\
\text { order factor } 3\end{array}$ \\
\hline \multirow[t]{3}{*}{ TIQ - Second order factor } & Pearson Correlation & 1 & $-0,698\left(^{* *}\right)$ & $-0,348\left(^{* *}\right)$ & 0,181 \\
\hline & Sig. (2-tailed) & & 0,000 & 0,001 & 0,102 \\
\hline & $\mathrm{N}$ & 86 & 78 & 82 & 83 \\
\hline
\end{tabular}


Correlation between Transformation Intervention Questionnaire and Leadership Strategy Questionnaire

The interrelationships between the variables were computed using Pearson's product moment correlation to identify the direction and strength of the relationships between each of the variables. Effect sizes, rather than inferential statistics were used to decide on the significance of the findings. Effect sizes of 0,1 ; 0,3 and 0,5 were seen as small, medium and large effect sizes respectively. Inter-correlation analyses were performed to assess the overall correlation between the theoretical dimensions of the Transformation Intervention Questionnaire and the dimensions of the Leadership Strategy Questionnaire II. The correlations are set out in Table 7.

There is no significant correlation between Transformation interventions and Factor 3 or Directive leadership $(r=0,18)$. There is a significant strong negative correlation with Factor 1 or Combined leadership styles (Transactional, Transformational and Empowering leadership styles) because $r=-0,69$. However, since the scales were inversed this means there was a significant strong positive correlation. There is a significant medium correlation with Factor 2 or Transformational leadership $(r=0,34)$.

\section{DISCUSSION}

The primary aim of the study was to explore the relationship between leadership styles and the implementation of transformation interventions. The aim of the study was not to measure leadership styles of the management but to focus on subordinates' perception of their manager's leadership style. The study also tested the null hypothesis that there is no relationship between leadership styles and the implementation of transformation interventions.

The findings of the research indicate that there is a strong relationship between the implementation of transformation interventions and perceived integrated leadership styles. This means that organisations that want to influence the implementation of transformation interventions need to encourage their managers to make use of leader behaviours such as "Self-reward", "Opportunity thought", "Contingent personal reward", "Participative goal setting", "Contingent material reward", "Assigned goals", "Vision", "Stimulation and inspiration", "Independent action" and "Encourage teamwork". What was noteworthy about this finding is that these dimensions (listed above) are associated with all four leadership styles as postulated by Manz and Sims (1991) and not just a single leadership style.

Implementation of transformation interventions has a medium correlation with perceived Transformational leadership style. Implementation of transformation interventions has no significant relationship with Directive leadership style. This means that aversive behaviour and instructions and command are neither necessary nor unnecessary for the implementation of transformation interventions.

According to the factor analysis there is sufficient evidence to support Manz and Sim's (1991) leadership theory. From the 15 factors 14 were identified in the first order factor analysis (Stimulation and inspiration was not factor analysed for there were only 2 items in this dimension), which places the reliability of the questionnaire above reproach. However, what must be noted is that many of the questions were repeated or rephrased in a very similar manner. This obviously would have increased reliability. Therefore, to a certain extent, the reliability scores can be seen as artificial reliability scores and future research could perhaps adapt the questionnaire.
Only 3 factors (Integrated, Transformational and Directive leadership) were extracted from this research. Consequently this research study does not fully support the four-factor leadership model (made up of Directive, Transactional, Transformational and Empowering leadership styles discussed under Leadership and leadership styles) proposed by Manz and Sims (1991). Factor 1(extracted from this research) includes behaviour types of all 4 leadership behaviours namely Directive leadership style (assigned goals), Transactional leadership style (contingent personal reward, and contingent material reward.

Transformational leadership style (vision, stimulation and inspiration) and Empowering leadership style (independent action, encourages self-reward, encourages opportunity thought and encourages teamwork). Factor 2 includes Transformational leader behaviours as in "Challenge to the status quo" and "Idealism" whilst "Contingent reprimand" is associated with Directive leader behaviours. "Aversive behaviour" and "Instruction and command" form the basis of Factor 3 and are associated with a Directive leadership style.

The above groupings of the research findings point to the fact that leaders do not need to have just a single leadership style to implement transformation interventions. Instead the study reveals that leaders need to employ all four leadership styles, depending on the context. This finding provides a possible answer to the question posed at the beginning of the research process, "What exactly is the 'right' leadership style and when should it be used?" Thus, despite the fact that the correlations are not causal, they suggest that leaders implementing transformation interventions need to adapt their leadership styles depending on the context.

What was unexpected in the findings was that Factor 1, referred to as "Integrated Leadership Styles", included "Assigned goals" which is a leader behaviour associated with a Directive leadership style. The dimension "Participative goalsetting" was also included in Factor 1. One would expect that in a modern mining organisation striving for world-class status, employees would prefer and expect to engage in participative goal-setting rather than have goals assigned to them. This points to the fact that the subordinates perceive that a leader who assigns goals for them would be effective in implementing transformation interventions as he or she would be providing them with a sense of direction. The study also indicates that Transactional leadership (employees receive something in exchange for following orders) is needed to aid the implementation of transformation interventions. This is surprising for one would expect the modern employee to take initiative to bring about transformation.

What was also unexpected was that the dimension "Contingent reprimand" (a dimension of Directive leadership) was grouped with Transformational leader behaviours in Factor 2. This indicates that subordinates expect their leaders to display transformational leader behaviours but also expect them to let them know when they perform poorly or when their work is not up to par.

A number of limitations of the study were identified. The use of a single organisation as the research site is a potential limitation on the ability to generalise these results. In addition to this, the fact that the research was based in a mining organisation makes it difficult to generalise the findings to any other organisation within another industry. The sample size was limiting. Future research would do well to collect larger data sets. The Transformation Intervention Questionnaire used in this study could be seen as a possible limitation. The Transformational Intervention Questionnaire was designed for this study using specific transformation interventions that is used by the leaders in the research site. Consequently, the questionnaire may not necessarily adhere to strict 
questionnaire design requirements and future research should take this into account. Individual perceptions of each of the variables measured could have been affected by employee morale. Morale in the group was at a low. There was resistance and uncertainty about the implementation of employment equity and lack of promotion opportunities for many of the White male employees.

Typically this kind of study is directed at the understanding of causal processes, which occur over time, yet the conclusions are going to be based on observations made at only one point in time. Babbie (1975), a relatively old source, but considered an evergreen, in his observation draws an analogy with taking a photograph. He states this limitation is somewhat akin to that of determining the speed of a moving object on the basis of a high-speed, still photograph, which "freezes" the movement of the object.

\section{Recommendations for future research}

Several avenues for future research are readily identifiable. A need for research that expands on the information obtained in this article could prove valuable. It is therefore advised that attempts should be made to replicate these analyses in a number of different industries. Similar research could be conducted with a larger sample.

Given that this study incorporated both qualitative and quantitative research methods, perhaps future research could take on a purely qualitative approach with in-depth interviews of both management and employees in a given organisation or organisations. The Leadership Strategy Questionnaire II by Manz and Sims utilised in the study, incorporated a selection of leader behaviours that was fairly extensive but was by no means exhaustive. Therefore, it is clearly possible that investigation of different leader behaviours may produce different results. Perhaps there are leadership styles conducive to a South African leadership climate that is not addressed in this particular questionnaire. The success or effectiveness of transformation interventions can only be seen over time. Perhaps future research could utilise a methodology that takes this factor into account and would present a better understanding of transformation as a causal process.

\section{ACKNOWLEDGEMENT}

The authors would like to thank R.Eiselen and W.C. Koster from Statcon, RAU, for their professional service and valuable contribution regarding the data analysis of this project.

\section{REFERENCES}

Applebaum, S.H. \& Wohl, I. (2000). Transformation or change: Some prescriptions for health care organizations. Managing Service Quality, 10 (5), 279-298.

Babbie, E.R. (1975). The practice of social research. California: Wadsworth Publishing.

Bass, B.M. \& Avolio, B.J. (1997). Full range leadership development. Manual for the Multifactor leadership questionnaire. California: Mind Garden.

Beck, J.D.W. \& Yeager, N.M. (2001). The leader's window: Mastering the four styles of leadership to build high-performing teams. California: Davies-Black Publishing.

Berr, S.A, Church, A.H. \& Waclawski, J. (2000). The right relationship is everything: Linking personality preferences to managerial behaviours. Human Resource Development Quarterly, 11 (1), 133-158.

Bless, C. \& Higson-Smith, C. (2000). Fundamentals of social research methods: An African perspective. Lansdowne: Juta.

Bogdan, R. \& Biklen, S.K. (1998). Qualitative research for education: An introduction to theory and methods. $3^{\text {rd }}$ ed. Boston: Allyn and Bacon.
Burton, L. (2002). Developing leadership in South Africa - An interview with Accenture's global leadership expert, Paul Taffinder. People Dynamics. Dec/Jan 2002, 21+

Bushe, G. R. (2001). Clear leadership: How outstanding leaders make themselves understood, cut through the mush and help everyone get real at work. California: Davies-Black Publishing.

Bussin, M. (2003). Factors driving changes to remuneration policy and outcomes. Unpublished doctoral thesis, Johannesburg: Rand Afrikaans University.

Creswell, J.W., Trout, S. \& Barbuto, J.E. (2003). A Decade of mixed methods writings: A retrospective. Retrieved May 30, 2004, from http://www.edra.org/resources/pdfs/drnv33n4.pdf.

De Koch,P.M. \& Slabbert, J.A. (2003). Transformational leadership in business organisations ascending to world-class status: A case study in the petrochemical industry. SA Journal of Industrial Psychology, 29 (1), 1-7.

Denzin, N.K. \& Lincoln, Y.S. (Eds). (2000). Handbook of Qualitative Research. $2^{\text {nd }}$ ed. Thousand Oaks: Sage Publications.

Flick, U. (1998). An introduction to qualitative research. London: Sage Publications.

Giber, D., Carter, L.L \& Goldsmith, M. (Eds). (2000). Linkage Inc's best practices in leadership development handbook. San Francisco: Jossey-Bass.

Godard, A. \& Lenhardt, V. (2000). Transformational leadership: Shared dreams to succeed. New York: Palgrave.

Hartog, D.N., \& Van Muijen, J. (1997). Transactional versus transformational leadership: An analysis of the MLQ. Journal of Occupational and Organisational Psychology, 70 (1), 19-35.

Hathaway, R.S. (1995). Assumptions underlying qualitative and quantitative research: Implications for institutional research. Research in higher education, 36 (5), 535-562.

Havenga, R. (2002). The new leadership challenge: Teaming principles with practices in times of change. Management Today, February 2002, $4^{+}$

Heifetz, R.A. \& Laurie, D.L. (1998). The work of leadership. In Harvard Business Review on leadership. USA: Harvard business school press.

Kanji, G.K. \& Moura, E.S. (2001). Measuring Leadership Excellence. Total Quality Management, 12 (6), 709.

Kotter, J.P. (1998). What leaders really do. In Harvard Business Review on leadership. USA: Harvard business school press.

Kouzes, J.M. \& Posner, B.Z. (2002). Leadership challenge. San Francisco: Jossey-Bass.

Leslie, J.B. \& Van Velsor, E. (1998). A cross national comparison of effective leadership and teamwork: Towards a global workforce. Human Resource Development Quarterly, 11 (1), 207-209.

MacNamara, C. (2004). An overview of leadership in organizations. Retrieved January 27, 2004, from http://www.mapnp. org/library/ldrship/ldrship.htm.

Manz, C.C. \& Sims, H.P. Jnr (1991). Superleadership: Beyond the myth of heroic leadership. Organizational Dynamics, 19 (4), 18-35.

Manz, C.C. \& Sims, H.P. (2001). The new Superleadership. San Francisco: Berrett-Koehler Publications.

Mester, C., Visser, D., Roodt, G. \& Kellerman, R. (2003). Leadership style and its relation to employee attitudes and behaviour. SA Journal of Industrial Psychology, 29 (2), 72-82.

Mining Charter. Retrieved March 15, 2004, from: http://www. dme.gov.za/minerals/ mining_charter.htm.

Mosia, M.S. (2003). The importance of different leadership roles in the strategic management process. Unpublished doctoral thesis. Johannesburg: RAU.

Pearce, C.L. \& Sims, H.P. Jnr. (2002). Vertical versus shared leadership as predictors of the effectiveness of change management teams: An examination of Aversive, Directive, Transactional, Transformational, and Empowering leader behaviours. Group Dynamics: Theory, Research and Practice, 6 (2), 172-197.

Peters, T. (2004). Reimagine: business excellence in a disruptive age. Management Today, 20 (6), 6-9. 
Salam, S., Cox, J.F. \& Sims, H.P. Jnr (1997). In the eye of the beholder: How leadership relates to 360 degree performance ratings. Group and organisational management. Retrieved June 23, 2004 from http://www7.kellogg, northwestern.edu/murmann/weeks/articles/week/10/ w10a3.doc

Smit, H. \& Carstens, L. (2003). The influence of leadership role competencies on organisation change outcome in the manufacturing industry in South Africa. SA Journal of Human Resource Management, 1 (2), 45-52.

Strauss, A. \& Corbin, J. (1990). Basics of qualitative research. Grounded theory procedure and techniques. Newbury Park: Sage Publications.
Tashakorri, A. \& Teddlie, C. (2003). Handbook of mixed methods in social and behavioural research. Thousand Oaks, CA: Sage Publications.

Thorn, M. (2003). Leadership in organizations: Global leadership competencies. Retrieved March 15, 2004, from http://www academy.umd.edu/publications/global leadership/marlene_ thorn.htm.

Van der Heyde, A. \& Roodt, G. (2003). Die verband tussen waargenome leierskap en die vlak van outonomie binne spanverband. South African Journal of Industrial Psychology, 29 (1), 8-17.

Williams, A., Woodward, S., Dobson, P. (2002) Managing change successfully. Using theory and practice to implement change Australia: Thomson. 